OPEN ACCESS

Edited by:

Yangfang Ye,

Ningbo University, China

Reviewed by:

Carlos Rosas,

National Autonomous University of Mexico, Mexico

Meng Li,

Key Laboratory of Marine Ecology and Environmental Sciences, Institute

of Oceanology, Chinese Academy

of Sciences (CAS), China

*Correspondence:

Christopher J. Coates

c.j.coates@swansea.ac.uk

Andrew F. Rowley

a.f.rowley@swansea.ac.uk

tThese authors have contributed equally to this work

Specialty section:

This article was submitted to Marine Fisheries, Aquaculture

and Living Resources,

a section of the journal

Frontiers in Marine Science

Received: 05 November 2021

Accepted: 14 December 2021

Published: 14 January 2022

Citation:

Coates CJ and Rowley AF (2022) Emerging Diseases and Epizootics

in Crabs Under Cultivation.

Front. Mar. Sci. 8:809759.

doi: 10.3389/fmars.2021.809759

\section{Emerging Diseases and Epizootics in Crabs Under Cultivation}

\author{
Christopher J. Coates ${ }^{\star t}$ and Andrew F. Rowley ${ }^{\star}$ \\ Department of Biosciences, Faculty of Science and Engineering, Swansea University, Swansea, United Kingdom
}

While most crab production for human consumption worldwide comes from capture fisheries, there is increasing production of selected species using aquaculture-based methods. This is both for the purpose of stock replacement and direct yield for human consumption. Disease has limited the ability to produce larval crabs in commercial hatcheries and this together with suitable feeds, are major hurdles in the sustainable development of cultivation methods. Juvenile and adult crabs are also subject to a range of diseases that can cause severe economic loss. Emerging pathogens/parasites are of major importance to crab aquaculture as they can cause high levels of mortality and are difficult to control. Diseases caused by viruses and bacteria receive considerable attention but the dinoflagellate parasites, Hematodinium spp., also warrant concern because of their wide host range and lack of control methods to limit their spread. This concise review examines the emerging diseases in several crabs that have been selected as candidates for aquaculture efforts including Chinese mitten crabs (Eriocheir sinensis), mud crabs (Scylla spp.), swimming crabs (Portunus spp.), blue crabs (Callinectes sapidus) and shore crabs (Carcinus maenas). The latter is also a prolific invasive species known to harbour diverse macro- and micro-parasites that can affect commercially important bivalves and crustaceans.

Keywords: Hematodinium spp., vibriosis, mud crabs, Chinese mitten crabs, Portunus spp., Callinectes sapidus, reoviruses, Scylla spp.

\section{INTRODUCTION}

The infraorder Brachyura contains over 7,000 species of true crabs making them one of the largest groups within the sub-phylum Crustacea. These crabs are found in marine, brackish and fresh waters with some species adapted to life in terrestrial habitats. The derivation of the term Brachyura literally means short-tail as during the larval stage the abdomen becomes reduced and folded underneath the developing crab-a process termed brachyurization (Cui et al., 2021).

Capture fisheries of brachyurans contribute substantially to food production globally as these have high protein, low saturated fat and micronutrients not abundant in diets based on the consumption of terrestrial animals (Azra et al., 2021; Golden et al., 2021). The gazami crab, Portunus trituberculatus is the most widely fished crab worldwide with landings in the Indo-Pacific region of over 500,000 $t$ in 2015 (Stevens and Miller, 2020). In northern Europe, the edible or brown crab (Cancer pagurus) fishery, although much smaller in tonnage landed, has an annual production of over 45,000 $\mathrm{t}$ (valued at $>€ 50$ million per annum to Ireland and the United Kingdom markets; Johnson et al., 2016). Similarly, Tanner (Chionoecetes bairdi) and snow crabs (C. opilio) in Alaskan and Canadian fisheries have yielded $c a .90,00$ and 147,000 t p.a., respectively, in recent 
years (Stevens and Miller, 2020). However, some of these and other fisheries are now unsustainable due to overfishing and environmental changes (e.g., Mullowney and Baker, 2020), and may not be sufficient to feed the rising global population (Costello et al., 2020; Foehlich et al., 2021). To address the limitations of capture fishing, aquaculture-based cultivation can provide larval-juvenile crabs for restocking purposes (e.g., Le Vay et al., 2008) and/or for producing marketable sized animals for human consumption. As many species of crabs have lengthy life history (developmental) cycles lasting several years, this makes it problematic to grow these through to a market size. Hence, those crabs with high market value and with rapid growth are more likely to be candidates for aquaculturebased cultivation.

Portunid crabs belonging to the family Portunidae are a large group of over 700 species including a few fast-growing crabs and some with high market value because of their taste and consistency of meat content. These "swimming crabs" often have large paddle-like limbs that facilitate their locomotory behaviour. As well as capture fisheries, there is also a market for soft-shell swimming crabs (i.e., post-moult individuals) as these attract a higher price and several short-term holding methods have been developed taking pre-moult crabs from the fishery, holding these in various water systems, and waiting for these to moult (Hungria et al., 2017). Crabs including Callinectes sapidus, Scylla spp. and Portunus spp. are sold as soft-shell crabs (Tavares et al., 2018).

The Chinese mitten crab, Eriocheir sinensis has a long history of cultivation stretching back to the 1960s when declines in wild caught crabs in China due to overfishing and obstructive engineering of waterways, triggered initial developments in hatchery techniques (Cheng et al., 2018). As a result of improved hatchery rearing methods, large scale production has become possible and the annual returns of mitten crabs in China rose from 17,500 $t$ in 1993 to 796,535 $t$ in 2014 (Cheng et al., 2018). By $2018,8 \%$ of global crustacean aquaculture production was mitten crabs behind whiteleg shrimp, Penaeus vannamei and red swamp crayfish, Procambarus clarkii at 53 and 18\%, respectively (FAO, 2020).

Disease is a key problem in aquaculture regardless of the type of production or the species targeted. For instance, major obstacles to larval production in hatcheries include diseases caused by opportunistic pathogens, such as vibrios (Sui et al., 2011; Zhang et al., 2014), a lack of knowledge of suitable diets (e.g., Holme et al., 2008; Waiho et al., 2018; Basford et al., 2021) and the cannibalistic behaviour of some crab species (Romano and Zeng, 2017). High stocking densities, poor water quality and other environmental parameters/stressors (e.g., temperature) can tip the balance in favour of the pathogen resulting in disease outbreaks (Coates and Söderhäll, 2021). Emerging diseasesusually defined as diseases that are new or are increasing in prevalence in new areas-can often appear when species are cultivated or moved into new geographical locations. These can cause high mortalities and appear in cycles or episodic events. Shellfish aquaculture (notably penaeid shrimp) are subject to "boom and bust" cycles in which disease-linked to inbreeding depression-is considered the major proximal cause in the "busted" industry (You and Hedgecock, 2019).
In this text we provide a succinct overview of the main diseases that threaten the establishment of crab aquaculture worldwide. We focus on several key species including the Chinese mitten crab (E. sinensis), mud crabs (Scylla spp.), swimming crabs (Portunus spp.), the Atlantic blue crab (C. sapidus), and the European shore crab (Carcinus maenas).

\section{CHINESE MITTEN CRABS, Eriocheir sinensis}

The mitten crab, E. sinensis, so-called because the males' hairy outgrowths on its claws resembling mittens, is native to East Asia. It lives in fresh water but moves into estuarine-coastal areas to breed. E. sinensis is a highly invasive crab and has spread into North America and Northern Europe where it can cause environmental damage because of its burrowing behaviour leaving riverbanks unstable. In the United Kingdom, it was first seen in the River Thames in 1935 (Ingle, 1986) with numbers increasing dramatically in the 1990s in several rivers throughout England (Clark et al., 1998; Herborg et al., 2005). Aquaculture production of this crab in China is important where it is viewed as a delicacy steamed with ginger and vinegar, and hence it has a high commercial value. Since the 1980's there has been a dramatic increase in hatchery production in China to 9 billion megalopa larvae by 2005 (Sui et al., 2011). In the first year, juvenile crabs are grown in ponds often in polyculture conditions. The grow out phase in year 2 brings them to market size often in ponds, lakes, pens, and paddy fields (Cheng et al., 2018).

Chinese mitten crabs under high stocking density culture conditions are subject to a range of diseases that have been found to cause high levels of mortality and hence production loss. These include white spot, tremor disease, hepatopancreatic necrosis disease, and milky disease (Table 1). White spot is a serious condition of shrimp that has decimated their production over the last few decades (Dhar et al., 2022). It is caused by a virus, the white spot syndrome virus, mainly found to affect shrimp production. An epidemic of this disease was reported in China by Ding et al. (2015) with high mortality. Tremor disease, a serious condition of cultured Chinese mitten crabs, was originally thought to be caused by rickettsia-like organisms (RLOs; Wang and Gu, 2002) but the infectious agent was later identified as a novel species of Spiroplasma, S. eriocheiris (Wang et al., 2011). It mainly occurs from May to October and causes high levels of mortality, but this bacterial disease can be treated with oxytetracycline (Liang et al., 2009). A further condition, termed hepatopancreatic necrosis disease is characterised by lesion development in the hepatopancreas, reduction in feeding activity and subsequent death (Ding et al., 2016, 2018). According to Ding et al. (2016), it is caused by the microsporidian parasite Hepatospora eriocheir, and interestingly, the first report of this disease was not in crabs in culture but in invasive crabs caught in the Thames estuary (Stentiford et al., 2011) implying both its wide geographical presence and as a potential biological control of these animals. Bateman et al. (2016) believe that Hepatospora spp., most likely belonging to the same species (eriocheiris) may be widespread in several species of crabs including edible crabs 
TABLE 1 | Key diseases of Chinese mitten crabs, Eriocheir sinensis in cultivation.

\begin{tabular}{|c|c|c|c|c|c|}
\hline Disease & Source & Causative agent & Mortality (\%) & Pathology & References \\
\hline White spot & China & $\begin{array}{l}\text { Viral, White spot } \\
\text { syndrome virus }\end{array}$ & $80-100$ & $\begin{array}{l}\text { Acute viral disease, virus multiplies in } \\
\text { haemolymph and hindgut wall cells }\end{array}$ & $\begin{array}{l}\text { Ding et al., 2015, } \\
2017\end{array}$ \\
\hline Tremor disease & China & $\begin{array}{l}\text { Bacterial, Spiroplasma } \\
\text { eriocheiris }\end{array}$ & $30-90$ & $\begin{array}{l}\text { Tremors, lethargy, loss of appetite. } \\
\text { Infection spread by haemocytes in } \\
\text { which they multiply intracellularly, to } \\
\text { nervous, muscular and connective } \\
\text { tissue }\end{array}$ & $\begin{array}{l}\text { Wang and Gu, 2002; } \\
\text { Wang et al., 2004, } \\
2011\end{array}$ \\
\hline \multirow[t]{3}{*}{$\begin{array}{l}\text { Hepatopancreatic } \\
\text { necrosis disease }\end{array}$} & $\begin{array}{l}\text { (1). FW pond culture, } \\
\text { China }\end{array}$ & $\begin{array}{l}\text { Microsporidian, } \\
\text { Hepatospora eriocheir } \\
(1,2) \text { or a non-infectious } \\
\text { disease (3) }\end{array}$ & $40-50$ & $\begin{array}{l}\text { Reduction in locomotory behaviour, } \\
\text { white focal patches in } \\
\text { hepatopancreas, muscle necrosis }\end{array}$ & Ding et al., 2016 \\
\hline & $\begin{array}{l}\text { (2). River Thames, } \\
\text { United Kingdom (wild) }\end{array}$ & & $\mathrm{N} / \mathrm{A}$ & & Stentiford et al., 2011 \\
\hline & $\begin{array}{l}\text { (3). Aquarium-based } \\
\text { experiment }\end{array}$ & & $?$ & & Shen G. et al., 2021 \\
\hline Milky disease & Northern China & $\begin{array}{l}\text { Fungal, Metschnikowia } \\
\text { bicuspidata }\end{array}$ & $>20$ & $\begin{array}{l}\text { White haemolymph with reduced } \\
\text { clotting, white muscle, leg loss }\end{array}$ & $\begin{array}{l}\text { Bao et al., 2021; } \\
\text { Ma et al., } 2021\end{array}$ \\
\hline
\end{tabular}

(C. pagurus) and parasitic pea crabs (Pinnotheres pisum). There is still some debate, however, on the aetiology of hepatopancreatic necrosis disease as some consider it to be an example of a non-infectious disease probably caused by environmental residues including insecticides (Shen G. et al., 2021) and metatranscriptomic analyses suggest that environmental factors may result in microbial dysbiosis in the hepatopancreas leading to disease (Shen Z. et al., 2021).

Non-native E. sinensis found in Holland have been shown to harbour the serious oomycete pathogen, Aphanomyces astaci, the causative agent of the crayfish plague (Tilmans et al., 2014). To our knowledge, there have been no published reports of infection in E. sinensis under cultivation caused by Hematodinium spp. which are common disease-causing agents of many species of decapods (Stentiford and Shields, 2005; Small, 2012). It is probable that its presence in fresh water rather than more haline conditions results in this lack of infection as infective dinospores of Hematodinium spp. do not survive low salinity conditions (Coffey et al., 2012). However, Hematodinium sp. has been observed in invasive E. sinensis in the River Thames in the United Kingdom (Kerr and Bateman personal communication, December 2021) showing that they are vulnerable to infection presumably depending on environmental salinity levels.

\section{MUD CRABS (MANGROVE CRABS) Scylla spp.}

There are four species of mud crabs that are important in food production. These include the Indo-Pacific swamp crab (mangrove crab), Scylla serrata found in Southeast Africa, India, China, Indonesia, Thailand, and Northeast Australia, and S. olivacea, S. paramamosain, and S. tranquebarica. The identification of these four species can be difficult (Keenan et al., 1998) and hence some fisheries data and reports of diseases for particular species may be inaccurate (FishStat, Li et al., 2018; FAO, 2020). The form of mud crab cultivation ranges from simple fattening and grow on using crabs/crablets collected from the wild through to larval hatchery production and subsequent grow on in ponds using monoculture and/or polyculture approaches (see Shelley and Lovatelli, 2011; Waiho et al., 2018; Syafaat et al., 2021a for reviews of culture methods). Around 95\% of aquaculture production of Scylla spp. relies on wild caught crabs (Stevens and Miller, 2020). Growth rates for mud crabs are high meaning they can be brought to market quickly and they have a good market value usually as live crabs (Paterson and Mann, 2011). Global aquaculture production of mud crabs rose to 89,390 $\mathrm{t}$ in 2016 (FishStat). By 2019, cultivation of S. serrata in Viet Nam, Indonesia and the Philippines reached 71,757, 39,900, and $20,772 \mathrm{t}$, respectively (OECD.stat). In southeast China, where mud crab cultivation is also of importance, unpublished data reported in Liu et al. (2011) revealed a loss of production due to disease in 2006 of $c a$. 14\% worth an estimated US\$ 32 million.

Because of the active culture of mud crabs in several countries including Bangladesh, China, Indonesia, The Philippines, Thailand and Viet Nam, several disease conditions have been reported and the causative agents fully characterised. Table 2 presents some of the main diseases found in S. serrata and $S$. paramamosain during cultivation-restricted to diseases where the causative agents have been identified. The reader should note that other disease conditions including those probably caused by bacteria (e.g., shell disease syndrome, red sternum syndrome) and protistans (e.g., egg infestation caused by Haliphthoros-like oomycete; Leaño, 2002) have been described (see Shelley and Lovatelli, 2011 and Santhanam, 2018 for reviews of these). For example, red sternum disease of $S$. serrata from crab farms in Thailand is associated with several morphotypes of bacteria seen in the tissues yet no definite causative agent has been elucidated (Areekijseree et al., 2010). The characteristics of this disease include progressive reddening of the ventral carapace and cloudiness of the haemolymph (probably caused by sepsis). Similarly, there are reports of cuticular abnormalities classified within the collective group of diseases termed shell disease syndrome, that may have a bacterial aetiology. Both 
of these are probably dysbiotic conditions where adverse environmental states cause changes in the cuticular (shell disease) and haemolymph (red sternum syndrome) microbiomes resulting in lesion development and septicaemia. Such diseases are unlikely to conform with Koch's postulates and so their cause(s) remain uncertain.

Viral diseases are prominent in mud crab cultivation and several of these have been identified in crab farms in China (Table 2). The three main viral conditions of current importance and associated with sleeping disease are caused by a reovirus, mud crab reovirus (MCRV), a dicistrovirus, mud crab dicistrovirus (MCDV) and finally a mud crab tombuslike virus (MCTV) as a co-infection with other reoviruses. The first of these, MCRV, a double stranded RNA virus, was first described in China in farms in 2007 (Weng et al., 2007) infecting Scylla sp. (S. paramamosain?) from a farm in Zhuhai, China experiencing sleeping disease. Viruses were found in the cytoplasm of unidentified connective tissue cells within the hepatopancreas and experimental infection of crabs either by injection or bath exposure with infected tissues caused $100 \%$ mortality (Weng et al., 2007). The second of these viruses associated with sleeping sickness is MCDV (=MCDV-1), a single stranded RNA containing dicistrovirus that also causes high mortality in mud crabs under cultivation (Zhang et al., 2011). This is distinct to the other viruses that infect mud crabs. Finally, mud crabs appear to be susceptible to infection by white spot syndrome virus, a well-known pathogen of penaeids. The virus can be found in several tissues of $S$. serrata but replication appears to mainly occur in the epithelial cells below the cuticle in the gill (Liu et al., 2009). Mud crabs may contract the virus by spillover from viraemic shrimp.
Several bacterial diseases of Scylla spp. have been reported (Table 2) including a recent report of a chitinolytic bacterium, Aquimarina hainanensis that caused high mortality in larvae in a crab hatchery (Midorikawa et al., 2020). It is closely related to other crustacean pathogens, such as Aquimarina penaei. This bacterium is also highly pathogenic to larvae of other crustaceans including $P$. trituberculatus, yet its virulence mechanisms remain unexplored. A second bacterial infection has been attributed to Photobacterium damselae subsp. damselae, also found to be highly pathogenic in many species of marine fishes and cetaceans (Rivas et al., 2013). Moreover, strains of this zoonotic bacterium can cause necrotising fasciitis in humans.

\section{SWIMMING CRABS Portunus pelagicus (BLUE SWIMMING CRABS, BLUE SWIMMER CRABS) AND Portunus trituberculatus (THE GAZAMI CRAB, THE HORSE CRAB, JAPANESE BLUE CRAB)}

Swimming crabs belonging to the genus Portunus are important commercial species in both fisheries and aquaculture. Portunus pelagicus is recognised as a species complex consisting of $P$. pelagicus, $P$. reticulatus, $P$. segnis and $P$. armatus that are morphologically, genetically, and geographically distinct (Lai et al., 2010). The two commercially important species of this group include $P$. armatus that is distributed in Australia and New Caledonia while $P$. pelagicus is mainly found in the West Pacific Ocean. World production of $P$. pelagicus was 265,869 and 29 t by capture fisheries and aquaculture, respectively, in 2016

TABLE 2 | Key diseases of mud crabs (Scylla serrata and S. paramamosain) in cultivation.

\begin{tabular}{|c|c|c|c|c|c|}
\hline Disease & Source & Causative agent & Mortality (\%) & Pathology & References \\
\hline $\begin{array}{l}\text { Sleeping } \\
\text { sickness }\end{array}$ & $\begin{array}{l}\text { Guangdong Province, } \\
\text { China }\end{array}$ & $\begin{array}{l}\text { Viral, mud crab reovirus } \\
\text { (MCRV) }\end{array}$ & $\begin{array}{l}80-100 \text { (in } \\
\text { infection trials) }\end{array}$ & $\begin{array}{l}\text { Sluggish behaviour, loss of feeding, } \\
\text { atrophy of hepatopancreas, empty } \\
\text { intestine, and yellow gills }\end{array}$ & $\begin{array}{l}\text { Weng et al., 2007; } \\
\text { Huang et al., } 2012\end{array}$ \\
\hline " & $\begin{array}{l}\text { S. paramamosain, } \\
\text { Zhuhai, Guangdong } \\
\text { Province, China }\end{array}$ & $\begin{array}{l}\text { Viral, mud crab } \\
\text { dicistrovirus (MCDV) }\end{array}$ & $\begin{array}{l}100 \text { by } 7 \text { days } \\
\text { (in infection } \\
\text { trials) }\end{array}$ & Viral multiplication in most tissues & $\begin{array}{l}\text { Zhang et al., 2011; } \\
\text { Guo et al., } 2013\end{array}$ \\
\hline " & $\begin{array}{l}\text { S. paramamosain, } \\
\text { Guangdong Province, } \\
\text { China }\end{array}$ & $\begin{array}{l}\text { Viral, mud crab } \\
\text { tombus-like virus (MCTV) }\end{array}$ & $?$ & Co-infection with other reoviruses & Gao et al., 2019 \\
\hline White spot & $\begin{array}{l}\text { Zhejiang Province, } \\
\text { China }\end{array}$ & Viral, WSSV & 34 & Epithelial cells of gills, cuticle infected & Liu et al., 2009, 2011 \\
\hline Vibriosis & $\begin{array}{l}\text { S. paramamosain, } \\
\text { China }\end{array}$ & $\begin{array}{l}\text { Bacterial, Vibrio } \\
\text { parahaemolyticus }\end{array}$ & $?$ & & Xie et al., 2021a \\
\hline- & $\begin{array}{l}\text { S. paramamosain, } \\
\text { Zhejiang Province, } \\
\text { China }\end{array}$ & $\begin{array}{l}\text { Bacterial, } \\
\text { Photobacterium } \\
\text { damselae subsp. } \\
\text { damselae }\end{array}$ & 20 & $\begin{array}{l}\text { Lethargy, lack of feeding behaviour, } \\
\text { darkened gills, pale hepatopancreas, } \\
\text { muscle necrosis }\end{array}$ & Xie et al., 2021b \\
\hline- & $\begin{array}{l}\text { S. serrata larvae in } \\
\text { hatchery in Ishigaki } \\
\text { Island, Japan }\end{array}$ & $\begin{array}{l}\text { Bacterial, Aquimarina } \\
\text { hainanensis }\end{array}$ & Mass mortality & $\begin{array}{l}\text { Tissue necrosis with accompanying } \\
\text { melanisation }\end{array}$ & $\begin{array}{l}\text { Dan and Hamasaki, } \\
\text { 2015; Midorikawa } \\
\text { et al., } 2020\end{array}$ \\
\hline Milky disease & $\begin{array}{l}\text { S. serrata in } \\
\text { Guangdong Province, } \\
\text { China }\end{array}$ & $\begin{array}{l}\text { Dinoflagellate, } \\
\text { Hematodinium sp. }\end{array}$ & $\begin{array}{l}\text { Acute } \\
\text { epizootics }\end{array}$ & $\begin{array}{l}\text { Cooked appearance, lethargy, milky } \\
\text { haemolymph, atrophy of epithelial } \\
\text { cells in hepatopancreas, coagulative } \\
\text { necrosis in heart }\end{array}$ & Li et al., 2008 \\
\hline
\end{tabular}


TABLE 3 | Key diseases of Portunus trituberculatus in cultivation.

\begin{tabular}{|c|c|c|c|c|c|}
\hline Disease & Source & Causative agent & Mortality (\%) & Pathology & References \\
\hline Vibriosis & China & $\begin{array}{l}\text { Bacterial, Vibrio } \\
\text { alginolyticus }\end{array}$ & $?$ & - & Liu et al., 2007 \\
\hline Vibriosis & $\begin{array}{l}\text { Megalopa in } \\
\text { commercial hatchery, } \\
\text { China }\end{array}$ & Vibrio harveyi & $\begin{array}{l}\text { Not given, } \\
\text { described as } \\
\text { "mass } \\
\text { mortality" }\end{array}$ & "weak," pale red bodies & Zhang et al., 2014 \\
\hline Vibriosis & $\begin{array}{l}\text { Jiansgu Province, } \\
\text { China }\end{array}$ & Vibrio metschnikovii & $30-40$ & $\begin{array}{l}\text { Lethargy, disturbed swimming } \\
\text { movement, dark pigmentation in } \\
\text { carapace, turbid haemolymph }\end{array}$ & Wan et al., 2011 \\
\hline Vibriosis & $\begin{array}{l}\text { Juvenile crabs from } \\
\text { Jiansgu Province, } \\
\text { China }\end{array}$ & Vibrio natriegens & $>85 \%$ & Lethargy, decreased feeding & Bi et al., 2016 \\
\hline $\begin{array}{l}\text { Microsporidiosis } \\
\text { (toothpaste crab } \\
\text { disease) }\end{array}$ & $\begin{array}{l}\text { Jiangsu Province, } \\
\text { China }\end{array}$ & $\begin{array}{l}\text { Microsporidian, Ameson } \\
\text { portunus }\end{array}$ & $?$ & $\begin{array}{l}\text { Chalky white muscle, toothpaste } \\
\text { appearance, numerous spores found } \\
\text { in muscle }\end{array}$ & Wang Y. et al., 2017 \\
\hline- & $\begin{array}{l}\text { Zhejiang Province, } \\
\text { China }\end{array}$ & Ciliate, Mesanophrys sp. & $>80$ & $\begin{array}{l}\text { Slow swimming, reduced food intake, } \\
\text { ciliates found in haemolymph, gills, } \\
\text { hepatopancreas and muscle }\end{array}$ & $\begin{array}{l}\text { Liu et al., 2020; } \\
\text { Perveen et al., } 2021\end{array}$ \\
\hline- & $\begin{array}{l}\text { Polyculture in Qingdao, } \\
\text { Shandong Province, } \\
\text { China }\end{array}$ & $\begin{array}{l}\text { Dinoflagellate, } \\
\text { Hematodinium perezi }\end{array}$ & $>90$ & $\begin{array}{l}\text { Trophont stages develop in a range of } \\
\text { tissues including muscle, } \\
\text { haemolymph and gills }\end{array}$ & $\begin{array}{l}\text { Wang J.F. et al., 2017; } \\
\text { Huang et al., } 2021\end{array}$ \\
\hline
\end{tabular}

(FAO, 2020). The gazami crab, P. trituberculatus is found along the Eastern coast of India, Japan, the South China Sea through to Australia. Global captive production in 2016 was 557,728 t (FAO FishStat; FAO, 2020) making it the most widely fished species of crab in the world. Depletion of localised crab stocks in some regions has resulted in aquaculture-based production designed to facilitate stock enhancement, restoration, and restocking, as well as human consumption. Cultivation methods are diverse as already described for mud crab aquaculture. Attempts to produce $P$. pelagicus in suspended net cages in Indonesia in a mixed polyculture system is a promising development (Kasmawati et al., 2020).

Vibriosis is an important disease of portunid crabs in cultivation. Various species of vibrios have been linked to disease including. V. alginolyticus, V. harveyi, V. metschnikovii, $V$. natriegens, and $V$. parahaemolyticus (Table 3). Crabs can become infected both in hatcheries during their larval phases as well as in later cultivation as juveniles/adults. Such diseases can cause high levels of mortality. Poor water quality and a lack of temperature control are likely to be contributory factors in such diseases.

A key pathogen of $P$. trituberculatus in China is Hematodinium perezi causing significant disease outbreaks in polyculture raised crabs with subsequent loss of production (Li et al., 2013, 2021; Wang J.F. et al., 2017; Huang et al., 2021). Infections peak during summer months when the environmental temperature is high $\left(>30^{\circ} \mathrm{C}\right)$. There is evidence that wild mud crabs, Helice tientsinensis in the vicinity of rearing areas for $P$. trituberculatus may be sinks/reservoirs for the parasite (Huang et al., 2021).

Of further note is the finding that $P$. trituberculatus is also a host for a variant of the Wenzhou shark flavivirus (Parry and Asgari, 2019)_indicating horizontal transfer of the virus from crabs to sharks or vice versa. While there is evidence of a host response to the multiplication of the virus in crab tissues, no pathology is currently available and so its importance as a driver of crab mortality both in the wild and in cultivation is unknown.

Moult death syndrome is a commonly observed phenomenon in several crustaceans including $P$. pelagicus. This fatal condition is characterised by animals in moult becoming trapped inside their old exoskeleton (i.e., dysecdysis). While the causes(s) of this is/are unclear, nutritional deficiency is a potential contributory factor and recent work has found that adding cholesterol to formulated diets significantly reduces this (Noordin et al., 2020).

\section{BLUE CRABS Callinectes sapidus}

The Atlantic blue crab, C. sapidus, has a wide range running along the Atlantic coast from Nova Scotia in the north to Argentina in the south. It is fished commercially and recreationally in many locations, e.g., Chesapeake Bay region and the Gulf of Mexico. In the former area, winter dredge surveys have been used to estimate crab abundance and these data have shown a general reduction in stock from over 800 million crabs in 1993 to ca. 260 million by 2007 but with yearly variances. Following conservation measures, by 2020 an estimated abundance of 405 million individuals of all ages was reported (Chesapeake Bay Blue Crab Advisory Report). ${ }^{1}$ Commercial production of soft-shell blue crabs in the United States has taken place for nearly two centuries (Tavares et al., 2018) making it one of the oldest forms of aquaculture in North America. There are two main production systems namely open (flow through)-reliant on local water supplies and with no control of environmental variables, and closed systems based on

\footnotetext{
${ }^{1}$ https://www.fisheries.noaa.gov/species/blue-crab
} 
recirculating technology. Closed systems offer better biosecurity and crabs have improved survival rates (Spitznagel et al., 2019). For example, peeler blue crab mortality in a commercial flow through system was found to be $33 \%$, while in a recirculating system it was less than half, 16\% (Spitznagel et al., 2019).

There is an extensive literature on the diseases of $C$. sapidus particularly in the Chesapeake Bay region of the United States that supports a large fishery (Jesse et al., 2021). Diseases include those caused by viruses (Johnson and Bodammer, 1975; Johnson and Lightner, 1988), bacteria (Krantz et al., 1969; Messick, 1998; Sullivan and Neigel, 2018), the parasitic dinoflagellate Hematodinium perezi (Messick and Shields, 2000; Huchin-Mian et al., 2017), various protistans, trematodes and ribbon worms (Messick, 1998; Shields, 2022). Because holding of crabs in softshell production facilities is short term ( $>14$ days) there is little time for them to become infected with new parasites and pathogens and hence diseases come from pre-existing conditions gained in the wild. The process of moulting is recognised as stressful to crustaceans in general (due to the major physiological expense) and this together with capture and handling stress, can result in mortality. It is probable that some of the deaths recorded in such facilities may be linked to infectious or noninfectious diseases. In a small survey of diseases encountered at a shedding facility in Louisiana, United States, the authors found tissue infestations by the commensal gill ciliate, Lagenophrys callinectes, $H$. perezi (by PCR alone), vibrios in haemolymph, reoviruses, the microsporidian, Ameson michaelis and shell disease (Rogers et al., 2015). They concluded that crab mortality seen in the facility could not be attributed with any certainty to any of these potential parasites and pathogens alone. More recently, there has been a great deal of emphasis placed on viral diseases in blue crab shedding facilities as these may be drivers of mortality (Spitznagel et al., 2019). Johnson (1977) was the first to record a novel viral disease in blue crabs that she observed mainly developing in the circulating haemocytes and in haematopoietic tissue but also in epithelial cells and the gill. This virus was originally referred to as reo-like virus (RLV) but later given the name C. sapidus reovirus 1 (CsRV1; Bowers et al., 2010; Flowers et al., 2016a,b). CsRV1 is like some other reoviruses in brachyuran crabs including $S$. serrata, E. sinensis and P. trituberculatus (Flowers et al., 2016b; Zhao et al., 2021). CsRV1 has been reported in ca. 20\% of capture fished C. sapidus (Flowers et al., 2016a) and at a variable prevalence across its host's geographic range from Northeast Atlantic through to Uruguay (Zhao et al., 2020). High CsRV1 loads in shedding facilities are associated with high crab mortality. For instance, infection by this virus is a significant predictor of mortality of pre-moult crabs and viral loads are highest in those crabs that die in these facilities (Spitznagel et al., 2019). The heightened presence of CsRV1 in crabs collected close to shedding plants (Flowers et al., 2018) may also suggest release of the virus from such areas and the authors considered that the potential practice of discarding dead crabs from such facilities may be a factor in these higher levels of infection. Finally, crabs held in recirculating systems, which also have enhanced biosecurity potential, have fewer diseases than those in flow through systems (Spitznagel et al., 2019).

\section{SHORE CRABS (EUROPEAN SHORE CRAB, GREEN CRAB, EUROPEAN GREEN CRAB) Carcinus maenas}

The European shore crab is an iconic inhabitant of the intertidal zone in northern European shores often found in rock pools to the delight of generations of children "crabbing" with nets and buckets. Its native range is from northern Africa in the south through to Iceland and Norway in the north. C. maenas is a hardy crab capable of withstanding changes in salinity, and tolerant to perturbations in temperature and oxygenation (Young and Elliott, 2020). Over the last two centuries it has become established in North America, Australia, and South America. In many of these regions it is considered a pest species damaging native fisheries (e.g., Cohen et al., 1995; Grosholz et al., 2000; Walton et al., 2002). Shore crabs are of limited commercial value as food both in their native and non-native environments although projects have expounded its culinary use in non-native areas as a way of controlling its population (Parks and Thanh, 2019). One important use of shore crabs is as a bait where soft post-moult crabs from pre-moult peelers are highly prized by recreational fishers targeting bass and cod. ${ }^{2}$ There have been pilot projects in the United Kingdom to determine the feasibility of collecting shore crabs from the wild and growing these on in flow through systems to produce soft crabs for the bait industry but, to our knowledge, none are currently in active commercial production.

There is a plethora of reports of diseases in shore crabs both in their native (Stentiford and Feist, 2005; Edwards et al., 2019; Davies et al., 2020a,b) and non-native (Goddard et al., 2005; Bojko et al., 2017, 2018; Blakeslee et al., 2020; Frizzera et al., 2021) ranges (Figure 1). Disease causing agents include viruses (Bojko et al., 2019; Bateman et al., 2021), bacteria (Spindler-Barth, 1976; Eddy et al., 2007), fungi (Davies et al., 2020a), microsporidians (Bojko et al., 2017), dinoflagellates (Chatton and Poisson, 1931; Stentiford and Feist, 2005; Hamilton et al., 2007, 2009; Davies et al., 2019), haplosporidians (Davies et al., 2020b), nematodes (Stentiford and Feist, 2005), acanthocephalans (Zetlmeisl et al., 2011), digeneans (Stentiford and Feist, 2005; Zetlmeisl et al., 2011; Blakeslee et al., 2015, 2020), and parasitic barnacles, Sacculina carcini (Mouritsen and Jensen, 2006; Powell and Rowley, 2008; Lützen et al., 2018; Mouritsen et al., 2018; Rowley et al., 2020). The extensive literature makes shore crabs one of the most highly studied decapods in terms of disease prevalence. In a recent survey of shore crab diseases in South Wales, United Kingdom a key endemic condition was found to be caused by the parasitic dinoflagellate, Hematodinium sp. with an overall prevalence of $c a$. 14\% (Davies et al., 2019). Other disease conditions included those caused by two novel species of haplosporidians (Davies et al., 2020b) and S. carcini (Rowley et al., 2020) but these were of lower prevalence and hence of less importance within crab populations.

Eddy et al. (2007) examined a novel disease of shore crabs in a pilot plant designed to grow on wild caught animals

${ }^{2}$ https://britishseafishing.co.uk/peeler-crab/ 

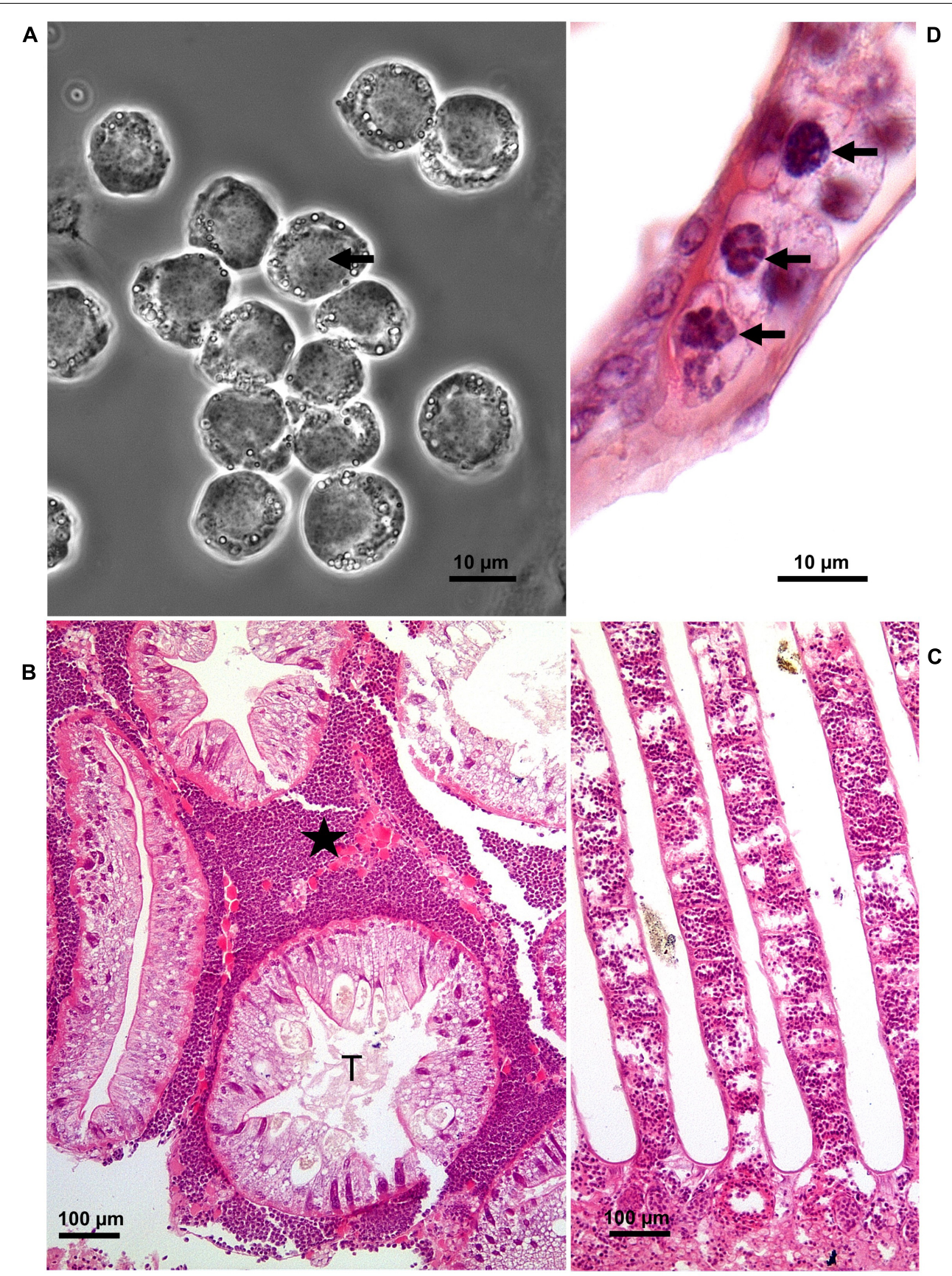

FIGURE 1 | Hematodinium infection of shore crab, Carcinus maenas. (A) Phase contrast micrograph of haemolymph replete with trophont stages of Hematodinium sp. The nuclei contain chromatin with a granular appearance (arrow) and the cytoplasm has many phase-bright droplets. (B) Histological section of hepatopancreas from a crab with a high severity infection. The interstitial spaces between the tubules (T) are swollen and replete with Hematodinium parasites ( $\left.{ }^{*}\right)$. (C) Section through the gill region of a heavily infected crab with numerous Hematodinium parasites in the lumen of swollen gill filaments. (D) High power micrograph of a histological section of gills showing the appearance of Hematodinium parasites with highly characteristic chromatin (arrows). Panels (B-D) are histological sections stained with haematoxylin and eosin.

for the bait market. They found that during the summer months with high water temperatures $\left(>25^{\circ} \mathrm{C}\right)$ that over $20 \%$ of crabs developed a condition that they described as "milky disease" as the haemolymph (blood) was milk colour. The cause of this was found to be a previously undescribed $\alpha$-proteobacterium related to the order Rhodobacteriales that resulted in septicaemia. This disease has also been reported at low prevalence in wild caught shore crabs (Eddy et al., 2007; Bojko et al., 2018) but was absent in a recent (2018-2019) large survey of shore crabs $(\sim 1,200)$ from two locations in 
South Wales, United Kingdom (unpublished observations by the authors).

\section{COMMON PATHOGENS AND THEIR GLOBAL RISK TO CRAB CULTURE}

While there are many common pathogens and parasites that can adversely affect crab production worldwide, the dinoflagellate parasites, Hematodinium spp. are perhaps some of the most notable. These parasites are host generalists in that they can infect a wide range of decapods worldwide and are endemic in several populations (Small, 2012; Shields, 2022). In some cases, such as velvet swimming crabs, Necora puber in France (Wilhelm and Mialhe, 1996) and snow crabs, Chionoecetes opilio in North America (Shields et al., 2005, 2007) they have caused epidemics that adversely affected fisheries. Furthermore, as already described, $H$. perezi infections of $P$. trituberculatus in China, have resulted in economic loss (Li et al., 2013; Wang J.F. et al., 2017) showing that these parasites are important in both fishery and aquaculture production of crabs. The life cycle of Hematodinium spp. is thought not to involve reservoirs and carriers outside the Decapoda. Motile dinospores are released from infected crabs as a cloud of infective stages and these penetrate susceptible animals resulting in infection that is localised in tissues including the haemolymph, hepatopancreas, gills and muscle (Figure 1; Stentiford and Shields, 2005; Shields, 2022). Ultimately, the trophont stage of parasites develop in the haemolymph with a concomitant decline in haemocyte number and the heavily affected animals become metabolically "exhausted" as the parasites utilise the host's resources (Stentiford et al., 2001; Shields et al., 2003). The timescale of initial infection through to death of the host varies from days to nearly a year and this is determined by a combination of the host species, the strain of parasite and the environmental conditions-especially the water temperature (see Smith and Rowley, 2015 for an overview). Apart from improvements in biosecurity, there are no prophylactic approaches available to control this infection.

Viral infections are common in crabs and an increasing number of pathogenic viruses have been identified in wild and cultured species of crustaceans (Bateman and Stentiford, 2017). Although particular emphasis has been placed on viral diseases of shrimp, a greater understanding of such agents has been achieved in mud crabs, Scylla spp. in culture (Weng et al., 2007; Jithendran et al., 2010; Zhang et al., 2011; Huang et al., 2012; Guo et al., 2013; Gao et al., 2019), blue crabs both in capture fisheries and aquaculture systems (Flowers et al., 2016a,b, 2018) and shore crabs, C. maenas in the wild (Bojko et al., 2019; Bateman et al., 2021). While the pathology and structure of the disease-causing viruses is often well-studied, the host range, potential reservoirs of disease and the effect of disease on wild populations, is less clear. The control and treatment of viral diseases in crustaceans, as in invertebrates in general, is still in its infancy.

Vibriosis is a common infection of many aquatic invertebrates. However, there are relatively few definitive reports of such infections in crabs either in the wild or under captive cultivation except for Scylla paramamosain (Table 2) and Portunus spp.
(Table 3). Identification of vibrios down to species level can be difficult requiring additional methods other than just general 16S RNA sequencing (e.g., Nagpal et al., 1998) and so some older reports on the identification of disease-causing vibrios based on biochemical (phenotypic) markers together with these alone can be misleading. Bacteria, including vibrios, remain important disease-causing agents in hatcheries (Valente and Wan, 2021) and together with the development of suitable diets are key challenges in crab cultivation (Dan and Hamasaki, 2015; Azra and Ikhwanuddin, 2016). Zoea and megalopa stages show rapid moulting and immature immune systems leaving them highly susceptible to chance infections. While antimicrobials including antibiotics, are commonly employed to control such diseases, their continued use is not sustainable due to environmental and heightened antibiotic resistance, so alternate strategies need to be explored to control these. Improvement in water quality $(\mathrm{pH}$, nitrogenous wastes, sterility via ozonation) and novel therapeutants (e.g., prebiotics, probiotics, immune stimulants, bacteriophages) are all potential strategies for development (Dan and Hamasaki, 2015; Ayisi et al., 2017; Doss et al., 2017; Culot et al., 2019; Valente and Wan, 2021; Rowley, 2022).

Crustaceans, especially those in wild stocks, are subject to parasitisation by macroparasites (e.g., microphallid digeneans and parasitic barnacles) but their importance in limiting production during cultivation is unclear. Removal of crabs from the wild for "fattening" is likely to introduce these conditions into farms but because such diseases have relatively long generation times their effect is probably limited unless they detract from the growth and/or market value of the product. Digenean parasites generally use crabs as their second intermediate hosts with molluscs as the primary intermediate hosts, and both fish and sea birds are the definitive host. Rearing crabs in polyculture systems will undoubtedly lead to infection if the primary intermediate hosts are present. The metacercarial stage of digeneans found in crustaceans may cause mortality by increased predation (e.g., Mouritsen and Jensen, 1997) and parasitic barnacles can limit fecundity in both male and female crabs resulting in losses of wild populations needed for broodstock and larvae for aquaculturebased cultivation (Waiho et al., 2021). Improved biosecurity measures are the only practical approach to limit the potential effects of these macroparasites as disease-free stocks of various crabs are not currently available.

\section{ENVIRONMENTAL FACTORS AND DISEASE}

It is well-established that disease outbreaks in both shellfish and fish are often linked to environmental perturbations/stressors. These include changes in (usually elevated) temperature, toxins, such as those from harmful algal blooms, metals, nitrogenous waste products and changes in $\mathrm{pH}$ (reviewed by Coates and Söderhäll, 2021). Aquatic animals because of their constant and intimate association with water, are highly vulnerable to such factors that can cause disease and trauma, i.e., non-infectious or sterile inflammation, on their own (Coates, 2022). Temperature is a major driver of disease, and although there is extensive 
literature on the mechanisms of how these impact on the host (e.g., Le Moullac and Haffner, 2000), pathogen (e.g., Baker-Austin et al., 2012; Le Roux et al., 2015; Sullivan and Neigel, 2018) and other environmental factors (e.g., Sullivan and Neigel, 2018) the temperature tolerance range for many crabs has not been widely explored and even then laboratory-based experiments may not fully reflect the intricacy of the real environment. Syafaat et al. (2021b) explored the thermal tolerance of early stages of mud crab, S. paramamosain in terms of growth, survival, moult frequency and gill health. The optimum temperature for the megalopa stage of these crabs was found to be between 28 and $30^{\circ} \mathrm{C}$. Gill health as measured by morphological changes, also showed paler gills at both low $\left(24^{\circ} \mathrm{C}\right)$ and high $\left(32^{\circ} \mathrm{C}\right)$ temperatures accompanied with changes in the thickness of the gill lamellae. However, how the parameters measured may impact on resistance to microbial disease was not studied. Shields (2019) also compared the thermal range of several species of crustaceans including C. sapidus with that of the parasitic dinoflagellate, $H$. perezi. Using the thermal ranges of the host and parasite, he concluded that the parasite could overcome the host defences at the higher margins of the thermal tolerance values resulting in faster multiplication of this parasite to the detriment of host tissues. There is extensive literature on the effect of climate change (largely temperature driven) on vibrios although most refers to human pathogens including $V$. cholerae, V. parahaemolyticus, and V. vulnificus (e.g., Vezzulli et al., 2013; Baker-Austin et al., 2017). Higher water temperatures generally favour faster growth of most vibrios and the enhanced production of virulence factors (e.g., Kimes et al., 2012; Feng et al., 2016; Lages et al., 2019; López-Cervantes et al., 2021) leaving them more likely to cause disease. It is the combination of temperaturedriven immune dysregulation of the host and enhanced microbial growth that results in disease episodes caused by vibrios.

\section{DISEASE SURVEILLANCE AND EMERGING DISEASES OF CRABS}

To our knowledge, with the exception of white spot syndrome virus, none of the disease-causing agents currently reviewed

\section{REFERENCES}

Areekijseree, M., Chuen-Im, T., and Panyarachun, B. (2010). Characterization of red sternum syndrome in mud crab farms from Thailand. Biologia 65, 150-156. doi: 10.2478/s11756-009-0228-y

Ayisi, C. L., Apraku, A., and Afriye, G. (2017). A review of probiotics, prebiotics, and synbiotics in crab: present research, problems and future perspectives. J. Shellf. Res. 36, 799-806. doi: 10.2983/035.036.0329

Azra, M. N., and Ikhwanuddin, M. (2016). A review of maturation diets for mud crab genus Scylla broodstock: Present research, problems and future perspective. Saudi. J. Biol. Sci. 23, 257-267.

Azra, M. N., Okomoda, V. T., Tabatabaei, M., Hassan, M., and Ikhwanuddin, M. (2021). The contributions of shellfish aquaculture to global food security: Assessing its characteristics from a future food perspective. Front. Mar. Sci. 8:654897. doi: 10.3389/fmars.2021.654897

Baker-Austin, C., Trinanes, J. A., Taylor, N. G. H., Hartnell, R., Siitonen, A., and Martinez-Urtaza, J. (2012). Emerging Vibrio risk at high latitudes in here are included in the Aquatic Animal Health Code (2021) of diseases adopted by the OIE, the World Organisation for Animal Health ${ }^{3}$ and so their surveillance and reporting may not be widely available in the public domain. Hence, it is difficult, if not impossible, to predict future epizootics of relevance to those species described herein. Improvements in biosecurity are difficult in aquaculture facilities where holding water is in direct contact with the environment and crabs are not from diseasefree stocks. While recirculating aquaculture systems (RAS) offer improved biosecurity, they have economic and social needs that leave them as unviable alternatives to some current production approaches. For an overview of disease surveillance of relevance to crab aquaculture, the reader is referred to the excellent review by Bondad-Reantaso et al. (2021).

Overall, a broad lack of temporal data on disease prevalence in crabs subject to cultivation hampers the accurate prediction, and management, of future epizootics, which should be addressed as a matter of urgency.

\section{AUTHOR CONTRIBUTIONS}

$\mathrm{CC}$ and $\mathrm{AR}$ researched, drafted, and edited the manuscript. Both authors contributed to the article and approved the submitted version.

\section{FUNDING}

$\mathrm{AR}$ and $\mathrm{CC}$ were supported by the BBSRC/NERC ARCH-UK network grant (BB/P017215/1).

\section{ACKNOWLEDGMENTS}

We thank Rose Kerr and Kelly Bateman of Cefas (Weymouth, United Kingdom) for sharing with us their unpublished observations of Hematodinium infections in Chinese mitten crabs.

\footnotetext{
${ }^{3}$ https://www.oie.int/en/what-we-do/standards/codes-and-manuals/aquaticcode-online-access $/$ ?id=169\&L=1\&htmfilechapitre_diseases_listed.htm
}

response to ocean warming. Nat. Clim. Chan. 3, 73-77. doi: 10.1038/nclimate 1628

Baker-Austin, C., Trinanes, J., Gonzalez-Escalona, N., and MartinezUrtaza, J. (2017). Non-cholera vibrios: The microbial barometer of climate change. Trends Microbiol. 25, 76-84. doi: 10.1016/j.tim.2016. 09.008

Bao, J., Jiang, H., Shen, H., Xing, Y., Feng, C., Li, X., et al. (2021). First description of milky disease in the Chinese mitten crab Eriocheir sinensis caused by the yeast Metschnikowia bicuspidata. Aquaculture 532:735984. doi: 10.1016/j. aquaculture.2020.735984

Basford, A. J., Makings, N., Mos, B., White, C. A., and Dworjanyn, S. (2021). Greenwater, but not live feed enrichment, promotes development, survival, and growth of larval Portunus armatus. Aquaculture 534:736331. doi: 10.1016/ j.aquaculture.2020.736331

Bateman, K. S., and Stentiford, G. D. (2017). A taxonomic review of viruses infecting crustaceans with an emphasis on wild hosts. J. Invertebr. Pathol. 147, 86-110. doi: 10.1016/j.jip.2017.01.010 
Bateman, K. S., Wiredu-Boakye, D., Kerr, R., Williams, B. A. P., and Stentiford, G. D. (2016). Single and multi-gene phylogeny of Hepatospora (Microsporidia)a generalist pathogen of farmed and wild crustacean hosts. Parasitology 143, 971-982. doi: 10.1017/S0031182016000433

Bateman, K. S., Kerr, R., Stentiford, G. D., Bean, T. P., Hooper, C., Van Eynde, B., et al. (2021). Identification and full characterisation of two novel crustacean infecting members of the family Nudiviridae provides support for two subfamilies. Viruses 13:1694. doi: 10.3390/v13091694

Bi, K., Zhang, X., Yan, B., Gao, H., Gao, X., and Sun, J. (2016). Isolation and molecular identification of Vibrio natriegens from diseased Portunus trituberculatus in China. J. World Aquacult. Soc. 47, 854-861.

Blakeslee, A. M. H., Keogh, C. L., Fowler, A. E., and Griffen, B. D. (2015). Assessing the effects of trematode infection on invasive green crabs in eastern North America. PLoS One 10:e0128674. doi: 10.1371/journal.pone.0128674

Blakeslee, A. M. H., Barnard, R. B., Matheson, K., and McKenzie, C. H. (2020). Host-switching among crabs: species introduction results in a new target host for native parasites. Mar. Ecol. Prog. Ser. 636, 91-106. doi: 10.3354/meps 13214

Bojko, J., Clark, F., Bass, D., Dunn, A. M., Stewart-Clark, S., Stebbing, P. D., et al. (2017). Parahepatospora carcini n. gen., n. sp., a parasite of invasive Carcinus maenas with intermediate features of sporogony between the Enterocytozoon clade and other microsporidia. J. Invertebr. Pathol. 143, 124-134. doi: 10.1016/ j.jip.2016.12.006

Bojko, J., Stebbing, P. D., Dunn, A. M., Bateman, K. S., Clark, F., Kerr, R. C., et al. (2018). Green crab Carcinus maenas symbiont profiles along a North Atlantic invasion route. Dis. Aquat. Org. 128, 147-168. doi: 10.3354/dao03216

Bojko, J., Subramaniam, K., Waltzek, T. B., Stentiford, G. D., and Behringer, D. C. (2019). Genomic and developmental characterisation of a novel bunyavirus infecting the crustacean Carcinus maenas. Sci. Rep. 9, 1-10. doi: 10.1038/ s41598-019-49260-4

Bondad-Reantaso, M. G., Fejzic, N., MacKinnon, B., Huchzermeyer, D., SericHaracic, S., Mardones, F. O., et al. (2021). A 12-point checklist for surveillance of diseases of aquatic organisms: a novel approach to assist multidisciplinary teams in developing countries. Rev. Aquacult. 13, 1469-1487. doi: 10.1111/raq. 12530

Bowers, H., Messick, G., Hanif, A., Jagus, R., Carrion, L., Zmora, O., et al. (2010). Physicochemical properties of double-stranded RNA used to discover a reolike virus from blue crab Callinectes sapidus. Dis. Aquat. Org. 93, 17-29. doi: $10.3354 /$ dao0 02280

Clark, P. F., Rainbow, P. S., Robbins, R. S., et al. (1998). The alien Chinese mitten crab, Eriocheir sinensis (Crustacea: Decapoda: Brachyura) in the thames catchment. J. Mar. Biol. Assoc. UK 78, 1215-1221. doi: 10.1017/ s002531540004443x

Chatton, E., and Poisson, R. (1931). Sur l'existence, dans le sang des crabes, de Péridiniens parasites: Hematodinium perezi n. g., n. sp. (Syndinidae). $C R$ Séances Soc. Biol. Paris. 105, 553-557.

Cheng, Y., Wu, X., and Li, J. (2018). "Chinese mitten crab culture: current status and recent progress towards sustainable development," in Aquaculture in China: Success Stories and Modern Trends, eds J.-F. Gui, Q. Tang, Z. Li, J. Liu, and S.S. De Silva (Hoboken: John Wiley and Sons), 197-217.

Coates, C. J. (2022). "Host defences of invertebrates to non-communicable diseases," in Invertebrate Pathology, eds A. F. Rowley, C. J. Coates, and M. M. A. Whitten (Oxford: Oxford University Press), 41-60. in press

Coates, C. J., and Söderhäll, K. (2021). The stress-immunity axis in shellfish. J. Invertebr. Pathol. 186:107492. doi: 10.1016/j.jip.2020.107492

Coffey, A. H., Li, C. W., and Shields, J. D. (2012). The effect of salinity on experimental infections of a Hematodinium sp. in blue crabs, Callinectes sapidus. J. Parasitol. 98, 536-542. doi: 10.1645/GE-2971.1

Cohen, A. N., Carlton, J. T., and Fountain, M. C. (1995). Introduction, dispersal and potential impacts of the green crab Carcinus maenas in San Francisco Bay. Mar. Biol. 122, 225-237.

Costello, C., Cao, L., Gelcich, S., Cisneros-Mata, M. A., Free, C. M., Froelich, H. E., et al. (2020). The future of food from the sea. Nature 588, 95-100. doi: 10.1038/s41586-020-2616-y

Cui, Z., Liu, Y., Yuan, J., Zhang, X., Ventura, T., Ma, K. Y., et al. (2021). The Chinese mitten crab genome provides insights into adaptive plasticity and developmental regulation. Nat. Commun. 12:2395. doi: 10.1038/s41467-02122604-3
Culot, A., Grosset, N., and Gautier, M. (2019). Overcoming the challenges of phage therapy for industrial aquaculture: A review. Aquaculture 513:734423. doi: 10.1016/j.aquaculture.2019.734423

Dan, S., and Hamasaki, K. (2015). Evaluation of the effects of probiotics in controlling bacterial necrosis symptoms in larvae of the mud crab Scylla serrata during mass seed production. Aquacult. Int. 23, 277-296. doi: 10.1007/s10499014-9815-1

Davies, C. E., Batista, F. M., Malkin, S. H., Thomas, J. E., Bryan, C. C., Crocombe, P., et al. (2019). Spatial and temporal disease dynamics of the parasite Hematodinium sp. in shore crabs, Carcinus maenas. Paras. Vect. 12:472. doi: 10.1186/s13071-019-3727-x

Davies, C. E., Malkin, S. H., Thomas, J. E., Batista, F. M., Rowley, A. F., and Coates, C. J. (2020a). Mycosis is a disease state encountered rarely in shore crabs, Carcinus maenas. Pathogens 9:462. doi: 10.3390/pathogens 9060462

Davies, C. E., Bass, D., Ward, G. M., Batista, F. M., Malkin, S. H., Thomas, J. E., et al. (2020b). Diagnosis and prevalence of two new species of haplosporidians infecting shore crabs Carcinus maenas: Haplosporidium carcini n. sp., and H. cranc n. sp. Parasitology 147, 1229-1237. doi: 10.1017/S0031182020000980

Dhar, A. K., Cruz-Flores, R., and Bateman, K. S. (2022). "Viral diseases of crustaceans," in Invertebrate Pathology, eds A. F. Rowley, C. J. Coates, and M. M. A. Whitten (Oxford: Oxford University Press), 368-399. in press

Ding, Z., Yao, Y., Zhang, F., Wan, J., Sun, M., Liu, H., et al. (2015). The first detection of white spot syndrome virus in naturally infected cultured Chinese mitten crabs, Eriocheir sinensis in China. J. Virol. Methods 220, 49-54. doi: 10.1016/j.jviromet.2015.04.011

Ding, Z., Meng, Q., Liu, H., Yuan, S., Zhang, F., Sun, M., et al. (2016). First case of hepatopancreatic necrosis disease in pond-reared Chinese mitten crab, Eriocheir sinensis, associated with microsporidian. J. Fish Dis. 39, 1043-1051. doi: $10.1111 /$ jfd.12437

Ding, Z., Wang, S., Zhu, X., Pan, J., and Xue, H. (2017). Temporal and spatial dynamics of white spot syndrome virus in the Chinese mitten crab, Eriocheir sinensis. Aquac. Res. 48, 2528-2537. doi: 10.1111/are.13089

Ding, Z., Pan, J., Huang, H., Jiang, G., Chen, J., Zhu, X., et al. (2018). An integrated metabolic consequence of Hepatospora eriocheir infection in the Chinese mitten crab Eriocheir sinensis. Fish Shellf. Immunol. 72, 443-451. doi: 10.1016/j.fsi.2017. 11.028

Doss, J., Culbertson, K., Hahan, D., Camacho, J., and Barekzi, N. (2017). A review of phage therapy against bacterial pathogens of aquatic and terrestrial organisms. Viruses 9:50. doi: 10.3390/v9030050

Eddy, F., Powell, A., Gregory, S., Numan, L. M., Lightner, D. V., Dyson, P. J., et al. (2007). A novel bacterial disease of the European shore crab, Carcinus maenas molecular pathology and epidemiology. Microbiology 153, 2839-2849. doi: 10.1099/mic.0.2007/008391-0

Edwards, M., Coates, C. J., and Rowley, A. F. (2019). Host range of the mikrocytid parasite Paramikrocytos canceri in decapod crustaceans. Pathogens 8:e252. doi: $10.3390 /$ pathogens 8040252

FAO (2020). The State of World Fisheries and Aquaculture 2020. Sustainability in Action. Rome: FAO. doi: 10.4060/ca9229en

Feng, B., Guo, Z., Zhang, W., Pan, Y., and Zhao, Y. (2016). Metabolome response to temperature-induced virulence gene expression in two genotypes of pathogenic Vibrio parahaemolyticus. BMC Microbiol. 16:75. doi: 10.1186/s12866-0160688-5

Flowers, E. M., Simmonds, K., Messick, G. A., Sullivan, L., and Schott, E. J. (2016a). PCR-based prevalence of a fatal reovirus of the blue crab, Callinectes sapidus (Rathbun) along the northern Atlantic coast of the USA. J. Fish Dis. 39, 705-714. doi: 10.1111/jfd. 12403

Flowers, E. M., Bachvaroff, T. R., Warg, J. V., et al. (2016b). Genome sequence analysis of CsRV1: A pathogenic reovirus that infects the blue crab Callinectes sapidus across its trans-hemispheric range. Front. Microbiol. 7:126. doi: 10.3389/ fmicb.2016.00126

Flowers, E. M., Johnson, A. F., Aguilar, R., and Schott, E. J. (2018). Prevalence of the pathogenic virus Callinectes sapidus reovirus 1 near flow-through blue crab aquaculture in Chesapeake Bay. USA Dis. Aquat. Org. 129, 135-144. doi: $10.3354 /$ dao 03232

Frizzera, A., Bojko, J., Cremonte, F., and Vázquez, N. (2021). Symbionts of invasive and native crabs, in Argentina: The most recently invaded area on the Southwestern Atlantic coastline. J. Invertebr. Pathol. 184:107650. doi: 10.1016/j. jip.2021.107650 
Foehlich, H. E., Couture, J., Falconer, L., et al. (2021). Mind the gap between ICES nations' future seafood consumption and aquaculture production. ICES J. Mar. Sci. 78, 468-477. doi: 10.1093/icesjms/fsaa006

Gao, Y., Liu, S., Huang, J., Wang, Q., Li, K., He, J., et al. (2019). Cryo-electron microscopy structures of novel viruses from mud crab Scylla paramamosain with multiple infections. J. Virol. 93, e2255-e2218. doi: 10.1128/JVI.02255-18

Goddard, J. H., Torchin, M. E., Kuris, A. M., and Lafferty, K. D. (2005). Host specificity of Sacculina carcini, a potential biological control agent of the introduced European green crab Carcinus maenas in California. Biol. Inv. 7, 895-912. doi: 10.1007/s10530-003-2981-0

Golden, C. D., Koehn, J. Z., Shepon, A., Passarelli, S., Free, C. M., Viana, D. F., et al. (2021). Aquatic foods to nourish nations. Nature 598, 315-320. doi: 10.1038/ s41586-021-03917-1

Grosholz, E. D., Ruiz, G. M., Dean, C. A., Shirley, K. A., Maron, J. L., and Connors, P. G. (2000). The impacts of a nonindigenous marine predator in a California bay. Ecology 81, 1206-1224.

Guo, Z.-X., He, J.-G., Xu, H.-D., and Weng, S.-P. (2013). Pathogenicity and complete genome sequence analysis of the mud crab dicistrovirus-1. Virus Res. 171, 8-14. doi: 10.1016/j.virusres.2012.10.002

Hamilton, K. M., Morritt, D., and Shaw, P. W. (2007). Molecular and histological identification of the crustacean parasite Hematodinium sp. (Alveolata, Syndinea) in the shore crab Carcinus maenas. Acta Protozool. 46, 183-192.

Hamilton, K. M., Shaw, P. W., and Morritt, D. (2009). Prevalence and seasonality of Hematodinium (Alveolata: Syndinea) in a Scottish crustacean community. ICES J. Mar. Sci. 66, 1837-1845. doi: 10.1093/icesjms/fsp152

Herborg, L. M., Rushton, S. P., Clare, A. S., and Bentley, M. G. (2005). The invasion of the Chinese mitten crab (Eriocheir sinensis) in the United Kingdom and its comparison to continental Europe. Biol. Invas. 7, 959-968. doi: 10.1007/s10530004-2999-y

Holme, M.-H., Zeng, C., and Southgate, P. C. (2008). A review of recent progress toward development of a formulated microbound diet for mud crab, Scylla serrata, larvae and their nutritional requirements. Aquaculture 286, 164-175. doi: 10.1016/j.aquaculture.2008.09.021

Huang, Q., Li, M., Wang, F., Song, S., and Li, C. (2021). Transmission pattern of the parasitic dinoflagellate Hematodinium perezi in polyculture ponds of coastal China. Aquaculture 538:736549. doi: 10.1016/j.aquaculture.2021.736549

Huang, Z., Deng, X., Li, Y., et al. (2012). Structural insights into the classification of mud crab reovirus. Virus Res. 166, 116-120. doi: 10.16/j.virusres.2012. 02.025

Huchin-Mian, J. P., Small, H. J., and Shields, J. D. (2017). Patterns in the natural transmission of the parasitic dinoflagellate Hematodinium perezi in American blue crabs, Callinectes sapidus from a highly endemic area. Mar. Biol. 164:153. doi: 10.1007/s00227-017-3185-y

Hungria, D. B., Tavares, C. P., Pereira, L. A., daSilva, U. D. A. T., and Ostrensky, A. (2017). Global status of production and commercialization of soft-shell crabs. Aquacult. Int. 25, 2213-2226. doi: 10.1007/s10499-017-0183-5

Ingle, R. W. (1986). The Chinese mitten crab Eriocheir sinensis H. Milne Edwards a contentious immigrant. London Nat. 65, 101-105.

Jesse, J. A., Agnew, M. V., Arai, K., Armstrong, C. T., Hood, S. M., Kachmar, M. L., et al. (2021). Effects of infectious diseases on population dynamics of marine organisms in Chesapeake Bay. Estuar. Coasts 2021:915. doi: 10.1007/s122237021-00915-4

Jithendran, K. P., Poornima, M., Balasubbramanian, C. P., and Kulasekarandian, S. (2010). Diseases of mud crabs (Scylla spp.): an overview. Ind. J. Fish. 57, 55-63.

Johnson, L., Coates, C. J., Albalat, A., Todd, K., and Neil, D. (2016). Temperaturedependent morbidity of 'nicked' edible crab, Cancer pagurus. Fish. Res. 175, 127-131. doi: 10.1016/j.fishres.2015.11.024

Johnson, P. T. (1977). A viral disease of the blue crab, Callinectes sapidus: histopathology and differential diagnosis. J. Invertebr. Pathol. 29, 201-209. doi: 10.1016/0022-2011(77)90194-X

Johnson, P. T., and Bodammer, J. E. (1975). A disease of the blue crab, Callinectes sapidus, of possible viral etiology. J. Invertebr. Pathol. 26, 141-143.

Johnson, P. T., and Lightner, D. V. (1988). Rod-shaped nuclear viruses of crustaceans: gut-infecting species. Dis. Aquat. Org. 5, 123-141.

Kasmawati, I., Asni, A., Ernaningsih, A., and Adimu, H. E. (2020). Aquaculture management of blue swimming crab (Portunus pelagicus) using integrated submerged net cage in Pangkep Regency waters, South Sulawesi, Indonesia. AACL Bioflux. 13, 3279-3286.
Keenan, C. P., Davie, P. J. F., and Cannon, L. R. G. (1998). A revision of the genus Scylla de Haan, 1833 (Crustacea: Decapoda: Brachyura: Portunidae). Raffles Bull. Zool. 46, 217-245.

Kimes, N., Grim, C., Johnson, W., Hasan, N. A., Tall, B. D., Kothary, M. H., et al. (2012). Temperature regulation of virulence factors in the pathogen Vibrio coralliilyticus. ISME J. 6, 835-846. doi: 10.1038/ismej.2011.154

Krantz, G. E., Colwell, R. R., and Lovelace, E. (1969). Vibrio parahaemolyticus from the blue crab Callinectes sapidus in Chesapeake Bay. Science 164, 1286-1287.

Lai, J. C. Y., Ng, P. K. L., and Davie, P. J. F. (2010). A revision of the Portunus pelagicus (Linnaeus 1758) species complex (Crustacea:Brachyura:Portunidae), with the recognition of four species. Raffles Bull. Zool. 58, 199-237.

Lages, M. A., Balado, M., and Lemos, M. L. (2019). The expression of virulence factors in Vibrio anguillarum is dually regulated by iron levels and temperature. Front. Microbiol. 10:2335. doi: 10.3389/fmicb.2019.02335

Le Moullac, G., and Haffner, P. (2000). Environmental factors affecting immune responses in Crustacea. Aquaculture 191, 121-131. doi: 10.1016/S00448486(00)00422-1

Le Roux, F., Wegner, K. M., Baker-Austin, C., Vezzulli, L., Osorio, C. R., Amaro, C., et al. (2015). The emergence of Vibrio pathogens in Europe: ecology, evolution and pathogenesis. Front. Microbiol. 6:830. doi: 10.3389/fmicb.2015.00830

Leaño, E. M. (2002). Haliphthoros spp. from spawned eggs of captive mud crab, Scylla serrata, broodstocks. Fung. Diver. 9, 93-103.

Le Vay, L., Lebata, M. J. H., Walton, M., Primavera, J., Quinitio, E., Lavilla-Pitogo, C., et al. (2008). Approaches to stock enhancement in mangrove-associated crab fisheries. Rev. Fish. Sci. 16, 72-80. doi: 10.1080/10641260701727285

Li, C. W., Song, S. Q., Liu, Y., and Chen, T. T. (2013). Hematodinium infections in cultured Chinese swimming crab, Portunus trituberculatus, in northern China. Aquaculture 396, 59-65. doi: 10.1016/j.aquaculture.2013.02.022

Li, C., Li, M., and Huang, Q. (2021). The parasitic dinoflagellate Hematodinium infects marine crustaceans. Mar. Life Sci. Technol. 3, 313-325. doi: 10.1007/ s42995-020-00061-z

Li, Y., Ai, C., and Liu, L. (2018). "Mud crab, Scylla paramamosain China’s leading maricultured crab," in Aquaculture in China: Success Stories and Modern Trends, eds J.-F. Giu, Q. Tang, A. Li, J. Liu, and S.S. De Silva (Hoboken: John Wiley), 226-233. doi: 10.1002/9781119120759.ch3_4

Li, Y. Y., Xia, X. A., Wu, Q. Y., Liu, W. H., and Lin, Y. S. (2008). Infection of Hematodinium sp. in mud crabs Scylla serrata cultured in low salinity water in southern China. Dis. Aquat. Org. 82, 145-150. doi: 10.3354/dao01988

Liang, T., Feng, Q., Wu, T., Gu, W., and Wang, W. (2009). Use of oxytetracycline for the treatment of tremor disease in the Chinese mitten crab Eriocheir sinensis. Dis. Aquat. Org. 84, 243-250. doi: 10.3354/dao02052

Liu, Q., Li, H. Y., Wang, Q., Liu, P., Dai, F. Y., and Li, J. (2007). Identification and phylogenetic analysis of a strain of Vibrio alginolyticus, a pathogen in Portunus trituberculatus with toothpaste disease. Mar. Freshwater Res. 28, 9-13.

Liu, W., Dong, Q., QingQing, P., and Xiaojun, Y. (2009). Studies on pathogenicity of the white spot syndrome virus and effect on hemolymph enzymes activities changes in mud crab Scylla serrata (Forskal). Acta Hydrobiol. Sinica 33, 11121117.

Liu, W., Qian, D., and Yan, X. J. (2011). Studies on pathogenicity and prevalence of white spot syndrome virus in mud crab, Scylla serrata (Forskal), in Zhejiang Province, China. J. Fish. Dis. 34, 131-138. doi: 10.1111/j.1365-2761.2010. 01221.X

Liu, X., Lei, Y., Ren, Z., et al. (2020). Isolation, characterization and virulence of Mesanophrys sp. (Ciliophora: Orchitophyryidae) in farmed swimming crab (Portunus trituberculatus) in eastern China. J. Fish. Dis. 43, 1419-1429. doi: $10.1111 /$ jfd. 13248

López-Cervantes, G., Álvarez-Ruiz, P., Luna-Suárez, S., Luna-González, A., Esparza-Leal, H. M., Castro-Martínez, C., et al. (2021). Temperature and salinity modulate virulence and PirA gene expression of Vibrio parahaemolyticus, the causative agent of AHPND. Aquacult. Int. 29, 743-756. doi: 10.1007/s10499-021-00654-0

Lützen, J., Jensen, K. H., and Glenner, H. (2018). Life history of Sacculina carcini Thompson, 1836 (Cirripedia: Rhizocephala: Sacculinidae) and the intermoult cycle of its host, the shore crab Carcinus maenas (Linnaeus, 1758) (Decapoda: Brachyura: Carcinidae). J. Crust. Biol. 38, 413-419. doi: 10.1093/jcbiol/ ruy044

Ma, H., Lu, X., Liu, J., Guo, S., Zhao, X., and Ye, S. (2021). Metschnikowia bicuspidata isolated from milky diseased Eriocheir sinensis: Phenotypic and 
genetic characterization, antifungal susceptibility and challenge models. J. Fish. Dis. 2021, 1-9. doi: 10.1111/jfd.13530

Messick, G. A. (1998). Diseases, parasites, and symbionts of blue crabs (Callinectes sapidus) dredged from Chesapeake Bay. J. Crust. Biol. 18, 533-548. doi: 10.1163/ 193724098 X00368

Messick, G. A., and Shields, J. D. (2000). Epizootiology of the parasitic dinoflagellate Hematodinium sp. in the American blue crab Callinectes sapidus. Dis. Aquat. Org. 43, 139-152. doi: 10.3354/dao043139

Midorikawa, Y., Shimizu, T., Sanda, T., Hamasaki, K., Dan, S., Lai, M. T. B. M., et al. (2020). Characterization of Aquimarina hainanensis isolated from diseased mud crab Scylla serrata larvae in a hatchery. J. Fish Dis. 43, 541-549. doi: $10.1111 /$ jfd.13151

Mouritsen, K. N., and Jensen, T. (1997). Parasite transmission between soft-bottom invertebrates: temperature mediated infection rates and mortality in Corophium volutator. Mar. Ecol. Prog. Ser. 151, 123-134.

Mouritsen, K. N., and Jensen, T. (2006). The effect of Sacculina carcini infections on the fouling, burying behaviour and condition of the shore crab. Carcinus maenas. Mar. Biol. Res. 2, 270-275. doi: 10.1080/174510006008 74752

Mouritsen, K. N., Geyti, S. N., Lützen, J., Høeg, J. T., and Glenner, H. (2018). Population dynamics and development of the rhizocephalan Sacculina carcini, parasitic on the shore crab Carcinus maenas. Dis. Aquat. Org. 131, 199-211. doi: $10.3354 /$ dao03290

Mullowney, D. R. J., and Baker, K. D. (2020). Gone to shell: Removal of a million tonnes of snow crab since cod moratorium in the Newfoundland and Labrador fishery. Fish. Res. 230:105680. doi: 10.1016/j.fishres.2020.105680

Nagpal, M. L., Fox, K. F., and Fox, A. (1998). Utility of 16S-23S rRNA spacer region methodology: how similar are interspace regions within a genome and between strains for closely related organisms? J. Micro. Meth. 33, 211-219. doi: 10.1016/S0167-7012(98)00054-2

Noordin, N. M., Zeng, C., and Southgate, P. C. (2020). Survival, molting pattern, and growth of early blue swimmer crab, Portunus pelagicus, juveniles fed diets containing varying levels of cholesterol. J. World Aquacult. Soc. 51, 255-265. doi: 10.1111 /jwas. 12623

Parks, M., and Thanh, T. (2019). The Green Crab Cookbook: An Invasive Species Meets a Culinary Solution. Massachusetts: Greencrab.org.

Parry, R., and Asgari, S. (2019). Discovery of novel crustacean and cephalopod flaviviruses: insights into the evolution and circulation of flaviviruses between marine invertebrate and vertebrate hosts. J. Virol. 93, e432-e419. doi: 10.1128/ JVI.00432-19

Paterson, B. D., and Mann, D. L. (2011). "Mud crab aquaculture," in Recent Advances and New Species in Aquaculture, eds R. K. Fotedar and B. F. Phillips (Oxford: Wiley-Blackwell), 115-135.

Perveen, S., Lei, Y., Yin, F., and Wang, C. (2021). Effect of environmental factors on survival and population growth of ciliated parasite, Mesanophrys sp. (Ciliophora: Scuticociliatia) infecting Portunus trituberculatus. Parasitology 148, 477-485. doi: 10.1017/S0031182020002127

Powell, A., and Rowley, A. F. (2008). Tissue changes in the shore crab Carcinus maenas as a result of infection by the parasitic barnacle Sacculina carcini. Dis. Aquat. Org. 80, 75-79. doi: 10.3354/dao01930

Rivas, A. J., Lemos, M. L., and Osorio, C. R. (2013). Photobacterium damselae subsp. damselae, a bacterium pathogenic for marine animals and humans. Front. Microbiol. 25:283. doi: 10.3389/fmicb.2013.00283

Rogers, H. A., Taylor, S. S., Hawke, J. P., Schott, E. J., and Anderson Lively, J. A. (2015). Disease, parasite and commensal prevalences for blue crab Callinectes sapidus at shedding facilities in Louisiana, USA. Dis. Aquat. Org. 112, 207-217. doi: $10.3354 /$ dao02803

Romano, N., and Zeng, C. (2017). Cannibalism of decapod crustaceans and implications for their aquaculture: A review of its prevalence, influencing factors, and mitigating methods. Rev. Fish. Sci. Aquacult. 25, 42-69. doi: 10. 1080/23308249.2016.1221379

Rowley, A. F. (2022). "Bacterial diseases of crustaceans," in Invertebrate Pathology, eds A. F. Rowley, C. J. Coates, and M. M. A. Whitten (Oxford: Oxford University Press), 400-435. in press

Rowley, A. F., Davies, C. E., Malkin, S. H., Bryan, C. C., Thomas, J. E., Batista, F. M., et al. (2020). Prevalence and histopathology of the parasitic barnacle, Sacculina carcini in shore crabs, Carcinus maenas. J. Invertebr. Pathol. 171:107338. doi: 10.1016/j.jip.2020.107338
Santhanam, R. (2018). Biology and Culture of Portunid Crabs of World Seas. Oakville: Apple Academic Press/CRC Press.

Shelley, C., and Lovatelli, A. (2011). Mud Crab Aquaculture - A Practical Manual. FAO Fisheries and Aquaculture Technical Paper. No. 567. Rome: FAO.

Shen, G., Shui, Y., Zhang, X., Song, K., Wang, Y., Xu, Z., et al. (2021). Hepatopancreatic necrosis disease (HPND) in Chinese mitten crab Eriocheir sinensis tightly linked to low concentration of two insecticides. Aquacult. Res. 52, 2294-2304. doi: 10.1111/are.15081

Shen, Z., Kumar, D., Liu, X., Yan, B., Fang, P., Gu, Y., et al. (2021). Metatranscriptomic analysis reveals an imbalance of hepatopancreatic flora of Chinese mitten crab Eriocheir sinensis with hepatopancreatic necrosis disease. Biology 10:462. doi: 10.3390/biology10060462

Shields, J. D. (2019). Climate change enhances disease processes in crustaceans: case studies in lobsters, crabs, and shrimps. J. Crust. Biol. 39, 673-683. doi: $10.1093 / \mathrm{jcbiol} / \mathrm{ruz} 072$

Shields, J. D. (2022). "Parasitic diseases of crustaceans," in Invertebrate Pathology, eds A. F. Rowley, C. J. Coates, and M. M. A. Whitten (Oxford: Oxford University Press), 458-502. in press

Shields, J. D., Scanlon, C., and Volety, A. (2003). Aspects of the pathophysiology of blue crabs, Callinectes sapidus, infected with the parasitic dinoflagellate Hematodinium perezi. Bull. Mar. Sci. 72, 519-535.

Shields, J. D., Taylor, D. M., and Pardy, A. L. (2005). Epidemiology of bitter crab disease (Hematodinium sp.) in snow crabs Chionoecetes opilio from Newfoundland, Canada. Dis. Aquat. Org. 64, 253-264. doi: 10.3354/dao0 64253

Shields, J. D., Taylor, D. M., O’Keefe, P. G., Colbourne, E., and Hynick, E. (2007). Epidemiological determinants in outbreaks of bitter crab disease (Hematodinium sp.) in snow crabs Chionoecetes opilio from Conception Bay, Newfoundland, Canada. Dis. Aquat. Org. 77, 1616-1580. doi: 10.3354/ dao01825

Small, H. J. (2012). Advances in our understanding of the global diversity and distribution of Hematodinium spp. - Significant pathogens of commercially exploited crustaceans. J. Invertebr. Pathol. 110, 234-246. doi: 10.1016/j.jip.2012. 03.012

Smith, A. L., and Rowley, A. F. (2015). Effects of experimental infection of juvenile edible crabs Cancer pagurus with the parasitic dinoflagellate Hematodinium sp. J. Shellf. Res. 34, 511-519. doi: 10.2983/035.034.0236

Spindler-Barth, M. (1976). A bacterial infection in the common shore crab Carcinus maenas and the fiddler crab Uca pugilator. Mar. Biol. 36, 1-4.

Spitznagel, M. I., Small, H. J., Lively, J. A., Shields, J. D., and Schott, E. J. (2019). Investigating risk factors for mortality and reovirus infection in aquaculture production of soft-shell blue crabs (Callinectes sapidus). Aquaculture 502, 289-295. doi: 10.1016/j.aquaculture.2018.12.051

Stentiford, G. D., Chang, E. S., Chang, S. A., and Neil, D. M. (2001). Carbohydrate dynamics and the crustacean hyperglycemic hormone $(\mathrm{CHH})$ : effects of parasitic infection in Norway lobsters (Nephrops norvegicus). Gen. Comp. Endocrinol. 121, 13-22. doi: 10.1006/gcen.2000.7575

Stentiford, G. D., and Feist, S. W. (2005). A histopathological survey of shore crab (Carcinus maenas) and brown shrimp (Crangon crangon) from six estuaries in the United Kingdom. J. Invertebr. Pathol. 88, 136-146. doi: 10.1016/j.jip.2005. 01.006

Stentiford, G. D., and Shields, J. D. (2005). A review of the parasitic dinoflagellates Hematodinium species and Hematodinium-like infections in marine crustaceans. Dis. Aquat. Org. 66, 47-70. doi: 10.3354/dao066047

Stentiford, G. D., Bateman, K. S., Dubuffet, A., Chambers, E., and Stone, D. M. (2011). Hepatospora eriocheir (Wang and Chen, 2007) gen. et comb. nov. infecting invasive Chinese mitten crabs (Eriocheir sinensis) in Europe. J. Invertebr. Pathol. 108, 156-166. doi: 10.1016/j.jip.2011.07.008

Stevens, B. G., and Miller, T. J. (2020). "Crab fisheries," in The Natural History of the Crustacea, Fisheries and Aquaculture, eds G. Lovrich and M. Thiel (Oxford: Oxford University Press), doi: 10.1093/0s0/9780190865627.003.0002

Sullivan, T. J., and Neigel, J. E. (2018). Effects of temperature and salinity on prevalence and intensity of infection of blue crabs, Callinectes sapidus, by Vibrio cholerae, V. parahaemolyticus, and V. vulnificus in Louisiana. J. Invertebr. Pathol. 151, 82-90. doi: 10.1016/j.jip.2017.11.004

Sui, L., Wille, M., Cheng, Y., Wu, X., and Sorgeloos, P. (2011). Larviculture techniques for Chinese mitten crab Eriocheir sinensis. Aquaculture 315, 16-19. doi: 10.1016/j.aquaculture.2010.06.021 
Syafaat, M. N., Azra, M. N., Waiho, K., Fazhan, H., Abol-Munafi, A. B., Ishak, S. D., et al. (2021a). A review of the nursery culture of mud crabs, genus Scylla: Current progress and future directions. Animals 11:2034. doi: 10.3390/ ani11072034

Syafaat, M. N., Azra, M. N., Mohamad, F., Che-Ismail, C. Z., Amin-Safwan, A., Asmat-Ullah, M., et al. (2021b). Thermal tolerance and physiological changes in mud crab, Scylla paramamosain crablet at different water temperatures. Animals 11:1146. doi: 10.3390/1ni11041146

Tavares, C. P. S., Silva, U. A. T., Pereira, L. A., and Ostrensky, A. (2018). Systems and techniques used in the culture of soft-shell swimming crabs. Rev. Aquacult. 10, 913-923. doi: 10.1111/raq.12207

Tilmans, M., Mrugała, A., Svoboda, J., Engelsma, M. Y., Petie, M., Soes, D. M., et al. (2014). Survey of the crayfish plague pathogen presence in the Netherlands reveals a new Aphanomyces astaci carrier. J. Invertebr. Pathol. 120, 74-79. doi: 10.1016/j.jip.2014.06.002

Valente, C. D. S., and Wan, A. H. L. (2021). Vibrio and major commercially important vibriosis diseases in decapod crustaceans. J. Invertebr. Pathol. 181:107527. doi: 10.1016/j.jip.2020.107527

Vezzulli, L., Colwell, R. R., and Pruzzo, C. (2013). Ocean warming and spread of pathogenic vibrios in the aquatic environment. Microb. Ecol. 65, 817-825. doi: 10.1007/s00248-012-0163-2

Waiho, K., Fazhan, H., Quinitio, E. T., et al. (2018). Larval rearing of mud crab (Scylla): What lies ahead? Aquaculture 493, 37-50. doi: 10.1016/j.aquaculture. 2018.04.047

Waiho, K., Glenner, H., Miroliubov, A., Noever, C., Hassan, M., Ikhwanuddin, M., et al. (2021). Rhizocephalans and their potential impact on crustacean aquaculture. Aquaculture 531:735876. doi: 10.1016/j.aquaculture.2020. 735876

Walton, W. C., MacKinnon, C., Rodriguez, L. F., Proctor, C., and Ruiz, G. M. (2002). Effect of an invasive crab upon a marine fishery: green crab, Carcinus maenas, predation upon a venerid clam, Katelysia scalarina, in Tasmania (Australia). J. Exp. Mar. Biol. Ecol. 272, 171-189. doi: 10.1016/S0022-0981(02) 00127-2

Wan, X., Shen, H., Wang, L., and Cheng, Y. (2011). Isolation and characterization of Vibrio metschnikovii causing infection in farmed Portunus trituberculatus in China. Aquacult. Int. 19, 351-359. doi: 10.1007/s10499-011-9422-3

Wang, J. F., Li, M., Xiao, J., Xu, W. J., and Li, C. W. (2017). Hematodinium spp. infections in wild and cultured populations of marine crustaceans along the coast of China. Dis. Aquat. Org. 124, 181-191. doi: 10.3354/dao03119

Wang, W., and Gu, Z. (2002). Rickettsia-like organism associated with tremor disease and mortality of the Chinese mitten crab Eriocheir sinensis. Dis. Aquat. Org. 11, 149-153. doi: 10.3354/dao048149

Wang, W., Wen, B., Gasparich, G. E., Zhu, N., Rong, L., Chen, J., et al. (2004). A spiroplasma associated with tremor disease in the Chinese mitten crab (Eriocheir sinensis). Microbiology 150, 3035-3040. doi: 10.1099/mic.0. 26664-0

Wang, W., Gu, W., Gasparich, G. E., Bi, K., Ou, J., Meng, Q., et al. (2011). Spiroplasma eriocheiris sp. nov., associated with mortality in the Chinese mitten crab, Eriocheir sinensis. Int. J. Syst. Evol. Microbiol. 61, 703-708.

Wang, Y., Li, X. C., Fu, G., Zhao, S., Chen, Y., Wang, H., et al. (2017). Morphology and phylogeny of Ameson portunus n. sp. (Microsporidia) infecting the swimming crab Portunus trituberculatus from China. Eur. J. Protistol. 61, 122-136. doi: 10.1016/j.ejop.2017.09.008
Weng, S.-P., Guo, Z.-X., Sun, J.-J., Chan, S.-M., and He, J.-G. (2007). A reovirus disease in cultured mud crab, Scylla serrata, in southern China. J. Fish. Dis. 30, 133-139. doi: 10.1111/j.1365-2761.2007.00794.x

Wilhelm, G., and Mialhe, E. (1996). Dinoflagellate infection associated with the decline of Necora puber crab populations in France. Dis. Aquat. Org. 26, 213-219.

Xie, J., Mei, H., JIn, S., Bu, L., Wang, X., Wang, C., et al. (2021a). Outbreak of vibriosis associated with Vibrio parahaemolyticus in the mud crab Scylla paramamosain cultured in China. Dis. Aquat. Org. 144, 187-196. doi: 10.3354/ dao03587

Xie, J., Mei, H., Jin, S., Bu, L., Wang, X., Wang, C., et al. (2021b). First report of Photobacterium damselae subsp. damselae infection in the mud crab Scylla paramamosain cultured in China. Aquaculture 530:73588. doi: 10.16/j. aquaculture.2020.735880

You, W., and Hedgecock, D. (2019). Boom-and-bust production cycles in animal seafood aquaculture. Rev. Aquac. 11, 1045-1060. doi: 10.1111/are.15377

Young, A. M., and Elliott, J. A. (2020). Life history and population dynamics of green crabs (Carcinus maenas). Fishes 5:4. doi: 10.3390/fishes5010004

Zetlmeisl, C., Hermann, J., Petney, T., Glenner, H., Griffiths, C., and Taraschewski, H. (2011). Parasites of the shore crab Carcinus maenas (L.): implications for reproductive potential and invasion success. Parasitology 138, 394-401. doi: 10.1017/S0031182010001344

Zhang, R., He, J., Su, H., Dong, C., Guo, Z., Ou, Y., et al. (2011). Identification of the structural proteins of VP1 and VP2 of a novel mud crab dicistrovirus. J. Virol. Meth. 171, 323-328. doi: 10.1016/j.jviromet.2010.09.010

Zhang, X. J., Bai, X. S., Yan, B. L., Bi, K. R., and Qin, L. (2014). Vibrio harveyi as a causative agent of mass mortalities of megalopa in the seed production of swimming crab Portunus trituberculatus. Aquacult. Int. 22, 661-672. doi: 10.1007/s10499-013-9695-9

Zhao, M., Behringer, D., Bojko, J., Kough, A. S., Plough, L., Tavares, C. P. D. S., et al. (2020). Climate and season are associated with prevalence and distribution of trans-hemispheric blue crab reovirus (Callinectes sapidus reovirus 1). Mar. Ecol. Prog. Ser. 647, 123-133. doi: 10.3354/meps13405

Zhao, M., Tavares, C. P. D. S., and Schott, E. J. (2021). Diversity and classification of reoviruses in crustaceans: A proposal. J. Invertebr. Pathol. 182:107568. doi: 10.1016/j.jip.2021.107568

Conflict of Interest: The authors declare that the research was conducted in the absence of any commercial or financial relationships that could be construed as a potential conflict of interest.

Publisher's Note: All claims expressed in this article are solely those of the authors and do not necessarily represent those of their affiliated organizations, or those of the publisher, the editors and the reviewers. Any product that may be evaluated in this article, or claim that may be made by its manufacturer, is not guaranteed or endorsed by the publisher.

Copyright (C) 2022 Coates and Rowley. This is an open-access article distributed under the terms of the Creative Commons Attribution License (CC BY). The use, distribution or reproduction in other forums is permitted, provided the original author(s) and the copyright owner(s) are credited and that the original publication in this journal is cited, in accordance with accepted academic practice. No use, distribution or reproduction is permitted which does not comply with these terms. 